\title{
Team Performance in Neighbourhood Security: An Ethnographic Presentation of Indigenous Traditional Security System in Badagry
}

\author{
Alaba Simpson \\ Covenant University, Ota
}

DOI: $10.36108 / \mathrm{NJSA} / 7002 / 50(0170)$

Vol. 5 Issue 1, 2007

\begin{abstract}
The paper discusses the neighbourhood security pattern in Badagry from an ethnographic perspective. It observes in particular, that Egun perception of security is located within the corporate existence of the people which is mostly based on their common ancestry, indigenous religious system and utmost respect for the social values of the land. Relying on the results of ethnographic studies, the paper pinpoints the central security role that is accorded to the traditional court system in the town. It emphasizes the position of this indigenous traditional judiciary institution as reflecting a cumulative catalogue of intricate networks of social control that are linked to the main-organs of security in the town. This is exemplified in the offices of Tayin, the female 'overseer' institution, the Kogan titled position of the Area leader and Zangbeto, the 'night people'. The paper highlights the prevailing role played by the Legba, the town's chief spiritual security officer that offers spiritual support for security efforts in the land. Finally, it concludes by noting that these separate but mutually dependent groups have lessons to offer for neighbourhood security conduct in other areas around Lagos since their carriage extends beyond the frontiers of mere The paper discusses the neighbourhood security pattern in Badagry from an ethnographic perspective. It observes in particular, that Egun perception of security is located within the corporate existence of the people which is mostly based on their common ancestry, indigenous religious system and utmost respect for the social values of the land. Relying on the results of ethnographic studies, the paper pinpoints the central security role that is accorded to the traditional court system in the town. It emphasizes the position of this indigenous traditional judiciary institution as reflecting a cumulative catalogue of intricate networks of social control that are linked to the main-organs of security in the town. This is exemplified in the offices ofTayin, the female 'overseer' institution, the Kogan titled position of the Area leader and Zangbeto, the 'night people'. The paper highlights the prevailing role played by the Legba, the town's chief spiritual security officer that offers spiritual support for security efforts in the land. Finally, it concludes by noting that these separate but mutually dependent groups have lessons to offer for neighbourhood security conduct in other areas around Lagos since their carriage extends beyond the frontiers of mere amorphous security groups that are commonly referred to as teams in everyday Nigerian parlance.
\end{abstract}

\section{Introduction}

Although the concept of security underlies all cultural environments, increased concern for neighbourhood security has become a point of convergence for many disciplines within the social sciences in recent times. Within the field of ethnography in particular, traditional patterns of ensuring 
neighbourhood security have appeared over the years to centre mostly on the applications of indigenous traditional social control machinery to everyday social relationships, thus engendering cohesion between the various arms of the community. Given the indigenous lifestyle pattern that characterizes Badagry town from its early history to the present times, the ethnographic presentation of relational team work surrounding neighbourhood security in the area as it is being presented in this paper does not attempt a departure from such a pattern of analysis. Rather, it offers an explanation that locates security within an overall pattern of legal, social and religious mechanisms as enunciated through the traditional court system that emphasizes team work. Examples abound in legal anthropology (Bohannan, 1967; Adamson 1967) of alternative law enforcement from which the case of the Egun may be better understood.

\section{Method Adopted}

The method adopted in the investigation that generated data for this paper is the ethnographic method. Ethnography is the standard method of enquiry in social anthropology. The method is considered indispensable to the writing of the corporate involvement of a people in neighbourhood security matters. A brief highlight of ethnographic methods in social anthropology is now attempted in order to throw some light on the contemporary reportage of an indigenous pattern for ensuring neighbourhood security as it is the case with the Egun of Badagry.

\section{A Brief Discussion on Ethnographic Method}

An understanding of the term ethnography will benefit from a separation of the word with particular regards to the prefix and the suffix. Consequently, "ethno" refers to the system of knowledge and cognition that typify a particular culture (Sturtevant, 1964) while the suffix" graphy" implies the general art of writing, describing or recording (Hanks and Potter, n.d). Ethnography is therefore characterized by the descriptive accounts of the culture of particular people.

Ethnographic data collection method is generally referred to as "fieldwork" and its antiquity dates back to the descriptive accounts given by early travellers, explorers, missionaries and so on (Evans-Pritchard, 1965, Mead, 1970; 1977). These accounts were subsequently used by anthropologists of the later part of the eighteenth century, in substituting their general theories which centered on the main issue of tracing the origin and development of social institutions. "Family" and" religion" were two of such prominent institutions that received considerable attention at the time (Wax, 1975; Evans-Pritchard, 1975). Contemporary conception of fieldwork in ethnography is however considered as forming an integral part of the training of professional social anthropologists. It entails, in its current 
practice, the taking up of residence by the ethnographer, among the people whose culture is to be described (Mead, 1970; Wax; 1975).

\section{Fieldwork among the Egun of Badagry}

Specifically, the data providing information for this paper derived from ethnographic studies that were variously carried out in Badagry town of the larger Badagry area of Lagos State. The periods of study were between January 1990 to February 1992, August to September 2001 (as part of the fieldwork for the UNESCO sponsored study on Slave Trade and Oral Tradition in Nigeria, Ghana and Benin (see Simpson, 2004), December 2002 to March 2003 and March to April 2004. Both the collection and analysis of ethnographic data among the Egun of Badagry, as discussed in this paper, serve as benchmarks against which the entire discussion on security is posited.

\section{The People of Badagry Town: Controversy over Ethnonym}

Situated about 57 kilometers from Lagos, Badagry town is inhabited by the Egun who are both the politically dominant and numerically preponderant ethnic group in the entire Badagry division of Lagos State in Nigeria. In recent times, the Egun in this area have been a subject of debate with particular regard to their ethnonym. Existing scholarly publications and relevant literature concerning this ethnic group have largely adopted the Egun title when referring to this cultural group (Avoseh, 1938; Hodder, 1961, 1962; Newbury, 1965; Herskovitz, 1967; Akinjogbin, 1967: Asiwaju, 1979) Avongnon, 1994). However, the fact that recent write ups on the people have adopted the ethnonym "Ogu" raises some problems of consistency particularly for scholars working in the area. Based on this, any sudden break in the use of this conventional ethnonym in the historiography of the people is likely to cause some confusion regarding especially their origin which they largely trace to the neighbouring Republic of Benin.

\section{Social Values, Social Control and Ties of Neighbourhood}

The Egun of Badagry town are a homogenous people and so merit study as a single unit. Traditional religion, which is vastly dominant among the people is largely centred around the acknowledgment and worship of vodun. Elsewhere, (see Simpson, 2001) it has been observed that the attitude of the Egun in Badagry town to culture becomes intelligible only when approached from the internal framework is a result of indigenous religion in the area.

Furthermore, the place of neighbourhood security becomes tenable to reason when we consider the fact that individuals belonging to their respective neighbourhoods as signified by quarters $(\mathrm{koh})$ are products of a chiefdom and as such become automatically involved in a chain of relationships that link them together with the high chiefs. They in turn head the individual quarters and who are subject to the King in whose jurisdiction rests the ultimate justice in the temporal domain. Interactions between the people are greatly guided by the beliefs and practices that are founded on the 
indigenous traditional beliefs of the town. Indeed, cooperation among them is grounded in the claim that they are all subject to the same authority. The place of values among the people is thus located within the purview of such beliefs and practices especially as social policy in the area is still very much reliant on indigenous traditional religion. Issues relating to neighbourhood security are therefore closely tied to such social policies and so have to be checked by countervailing mechanisms that are entrenched in the overall values of the community.

Indigenous traditional security has remained a highly valued attribute of the culture of the people who inhabit Badagry town as very little is left to formal governmental or individual organizational security organs to handle. This area has remained impervious to the attendant effects of urbanization that seem typical of the case with its immediate neighbours in the Lagos geographical enclave. The latter reveals a situation whereby accelerated crime rate and social order have necessitated the use of neighbourhood gates (mounted on nearly every street entrance), neighbourhood security gate officials, dogs, private security agents, the police, neighbourhood 'vigilantes', the indigenous Yoruba security force known as Oduwa People's Congress (OPC) and from time to time, the staging of Oro, the traditional security cult in curtailing the effect of such social malaise.

It is interesting to note however that contemporary concern with issues .related to neighbourhood security in Badagry has remained consistent and somehow adamant in the essential application of the social values of the town to addressing issues of security. Neighbourhood security in the area has thus placed great reliance on indigenous traditional security forces that highlight the values of the people in the area. These forces, which largely exemplify the age-old pattern of corporate existence and values that are common to all Egun communities in Nigeria and across the coast of West Africa, are a combination of indigenous knowledge that have been passed down over generations in relation to the overall well-being of the individual.

Accordingly, neighbourhood security in the town consists of an intricate network of indigenous traditional social control machinery that is exemplified through the celebrated traditional court system, with specific contributions from three other fundamental structures of the town. These are: the female' overseer' institution of Tayin, the Kogan titled position of the area leader and Zangbeto, the 'night people' _ Through the workings of these four separate but related organs of society in Badagry town, the checks and balances of customs and values are channeled towards ensuring neighbourhood security in the area.

The typical case of the neighbourhood security based conduct adopted in the traditional court system will be used in this paper to describe the manner in which interrelated security matters are approached in the town, thus highlighting the existing team work dimension that forms the thrust of our 
present consideration. Egun and Yoruba have been living together in the larger area of Badagry for a very long time. This can be seen as a testimony to the success of neighbourhood security management among the two groups. It is also possible to conceive of the synergy that typifies the duty performance in the security pattern in Badagry town along the line of the reason enunciated by Akinjogbin (1994) concerning why Badagry deserves to be studied. According to him (1994:3),

.. it is a border community between two African language groups the Yoruba and the Ogu. As a town which integrates two different languages even though within the same cultural continuum, Badagry has characteristics that could teach humanity some lessons in peaceful co-existence.

Overall, the determinant strategies for institutionalizing neighbourhood security in Badagry town have always being drawn from the backlog of a catalogue of beliefs and practices that are largely reflective of the values of the people in the area.

\section{Field Observations on Matters of Security}

It is important to present a brief history of the position of the individual forces that combine to make up the security team that is enjoyed by the indigenes of Badagry. I start with a discussion of the spiritual position on the overseer shrine of Legba, the umbrella security force to which each of the four core security agents with whom we are concerned in this paper are separately affiliated.

The individual organs that make up the security team in Badagry town will thus be examined. The indigenous traditional court system will be preceded by a discussion of the other three organs of security as represented in the respective offices of Kogan, Zangbeio and the institution of Tayin. This is in order to reveal the individual portfolio of the team members and the pathway that is adopted by them in channeling the course of security related to their offices. The court system is indeed a show case of the cumulative results of the efforts of the individual organs related to security in the town.

\section{The Shrine of Legba, the Indigenous Traditional Chief Security}

All of the four security organs being discussed in this paper are affiliated to Legba (also known as Tolegba) shrine which is regarded as the utmost spiritual security symbol, the deity whose presence is known to be recognized in all Egun communities. All of these arms of neighbourhood security in Badagry town are therefore subsumed, both individually and collectively under the indigenous spiritual security umbrella of Legba, whose shrine is situated at the entrance of the town.

As one of the deities of Badagry town, Legba is associated in Egun mythology with the devil albeit with special attributes that position it as 'The wicked and mischievous spirit of the town who drives evil away'. The 
overall acknowledgment of the deity as one which is associated with mischief and wickedness consists in the communal belief that it ensures the warding off of evil from the community. The Egun explains the seeming irony that is consisted within the idea of evil warding away evil with the popular statement that 'it is the wicked spirit itself that can consistently deal with wickedness on the earthly realm'. Based on this, Legba is communally associated with the attributes of a warring soldier, dangerous, yet protective in the performance of its assignment concerning the security of the town.

Oral tradition has it among the Egun that Legba shrine is always found at the entrance of any Egun settlement. This explains the present position of the shrine right at the entrance of Badagry town where it is believed to be on a twenty-four hour surveillance. Settlements around Badagry town are also believed to enjoy the protective custody of the Legba shrine. It is important to note that this shrine has been an age-old sign post in the area and is continuously sited by interested visitors to the town.

\section{Kogan: Area Leaders and Area Security}

$\underline{\text { Kogan }}$ are area leaders from within each quarter in Badagry town. They are responsible to the high chiefs in the administration of the respective quarters. Area Leaders work hand in hand with these high chiefs by giving regular briefings to them concerning the respective quarters. In essence, they act as overseers to the affairs of the people, looking out for issues that threaten the security of the area and dealing with them at the area level while transferring difficult cases to the High chiefs who would in turn handle them at the High chief s palace. Cases that are not successfully treated at this level are usually transferred to the Royal Council of the Akran where it will be reviewed and the individuals involved will be summoned to the traditional court at the next hearing.

\section{Zangbeto the Night People}

Zangbeto is the indigenous traditional religious security group that is common to all Egun land. Although their security activities cover the day, Zangbeto is more active at night as reflected by the word "Zan", which implies "night". The word "gbeto" on the other hand, implies "people". Hence, the literal meaning of "Zangbeto" is "night people".

People of questionable nocturnal movements in Badagry are usually accosted by members of the Zangbeto group. They are usually detained through the night with some form of punishment that would ensure their being awake till the morning when they will be reported to the heads of the quarter within where they were caught. Such cases of "night wandering" have been brought to the palace at daybreak following the night arrest. I had a personal encounter once, with these traditional security administrators, although I was not brought to court. I was in the company of one of my 
resident Egun friends who live at the Ahovikoh area and some members of staff of the Lagos State University. We were all together until around midnight when. I was being taken in the car back to the palace when we were arrested. We were detained for interrogation and released soon after, my colleagues being ordered to turn back immediately to the guest house while I was escorted to my destination by my Egun friend.

\section{Family Security: The Institution of Tayin}

The Institution of paternal aunts (Tayin) plays an important part in the dayto-day running and subsequent security of the family aspect of social life in Badagry town. Tayin are the ones in charge of peace-keeping within the typical Egun family. They represent the family before the ancestors (kubitio), with which every Egun individual is expected to keep regular communication for the essential purpose of I protecting' the lineage from any impending doom. Also the most important decisions are usually left for the Tayin's approval, since women (Yonsi) are considered to be the mothers of ancestors (Kubito) and consequently the mothers of living fathers $\underline{(\text { Oto })}$ within the community. Their position in the community is thus usually not treated with scant regard within the family and the larger community. Erring children are quick to change their ways at the approach of Tayin in a typical Egun household.

In essence, Tayin in: Egunland are usually in charge of character moulding, a cultural aspect which is embeded in the domain of socialization and enculturation. Tayin in Badagry town are very knowledgeable about diverse aspects of family issues and traditions. Where peace and security appear to be threatened within the family, they engage in the application of the indigenous Tovi-Novi. The incumbent king of Badagry, (Wheno Aholu Menu Toyi 1, Akran of Badagry) (2004) has referred to this indigenous peaceseeking pattern as a powerful instrument in the maintenance of peace and order in Badagry town. This is one major reason why the indigenous traditional court that is headed by the king adopts this method in addressing issues of security in the town.

\section{Traditional Court System and Neighbourhood Security}

The overall structure of traditional government in the town has remained over the centuries, a channel through which the various aspects of security in the town is given a voice. On the third day of the market (Ahime) which traditionally runs every nine days but is increasingly becoming a daily market (Simpson 1994), the indigenous traditional court in the town usually convenes to attend to issues that relate to the security of the town. The meeting is usually arranged to coincide with the market day in order to ensure the presence of all that are summoned to court as well as those that desire to listen to on-going cases at the traditional court. The venue is the hall within the palace of the Wheno Aholu, in which the king's throne overlooks the hall from an elevated platform. 
Before the meeting is fixed, cases of dispute between individuals whether brought by the members of the Royal Council of the Akran or reported directly by aggrieved indigenes would first have been discussed internally at a caucus meeting of the Royal Council of the Akran. Records of such cases are kept by the secretary to the palace. Messages are then sent to the disputing parties to appear in court on specified dates. This assignment is carried out by the palace clerk and town crier. The royal message is considered and indeed treated as requiring haste among the Egun, portraying the awesome power accorded to the king. It is considered taboo for anyone to defy such warrants as this would be termed as defiance against the king who. is the representative of the gods. Where some form of reluctance is shown by the person being summoned, the royal staff is sent to such a person and instant response to the kingly call usually follows.

\section{The Sitting of the Traditional Court}

The meeting which is also popularly referred to as "sitting" of the Royal Council, usually starts by 10a.m. Shortly before, people who have come to attend, hear and observe the cases at the court would be seen hanging about the outer court of the palace. By 10.am, they begin to go in and take their seats in the Palace Hall. Before this time, the king and other members of the Council would have been together in the main sitting room at the inner chamber of the palace together with the two ahosi (wives) of the Wheno Aholu. The wives of the king are expected to attend every sitting in their individual capacity as traditional title holders.

Led by the secretary to the palace, the members of the Royal Council of the Akran also come in to take different seats on the upper platform of the royal section of the hall as well as the first few rows in the sitting arrangement in the hall. The king and his wives are the last to come in. At the approach of the king, everyone gets up with a shout of "Hawe!", meaning "Long live your Royal Highness!". The king greets them in return and sits down after which everyone would sit.

\section{Security Priest and the Commencement of Court Hearing}

The importance of the issue of security to the community is particularly echoed in the overall conduct of the gathering which is usually preceded with prayers by Togbeji, the high priest of Legba. Togbeji takes charge of this opening section of the traditional court sitting because of the great importance that is attached to issues related to security in the town, and to his own position as the chief priest of the security shrine. Cases treated at this powerful traditional court usually range from land matters, family issues, trade and intra-group disputes to general public disturbances. 


\section{Tovi-Novi: Application of the Kin-Specific Dialogue Pattern}

Dispute settlement in indigenous traditional court sessions in Badagry town is usually carried out through the process of mediation by the elders of the town. The process, which is usually applied by paternal aunts in Egun families in attending to family related security matters is known as Tovi-Novi (System of kinship dialogue).

In applying the method of Tovi-Novi during the traditional court sessions, these elders conduct the affairs of the court as though they were negotiating peace among members of a specific family. They therefore rely greatly on the foundational basis of the traditional values of Badagry town. The occasions usually provide for the individual elder, whether male or female, regular opportunities for the display of eloquence in earmarking the related values of the land as points of reminders and admonition to the disputing parties. The use of carefully chosen and relevant proverbs and dialogues generated by the esoteric knowledge and authority in the indigenous culture is usually combined with a lot of persuasive tactics in the attempt to mete out justice. Sometimes, songs are rendered to drive home the point that peace and security (jijohoho) remain the basic platform upon which the strong bond of unity that can keep the people together for the good of the land can thrive.

From time to time, particularly when the cases of dispute being handled are those that are related in one way or the other to specific family issues, songs that invite the mercies of God and the benevolent spirits of the ancestors (Kubito) as well as the wisdom of the elders are rendered, particularly by the female members of the town who are present during the occasion. Some of these songs reveal the fundamental values of the town which recognize the existence of a most high God known as Mawu and who is present in the affairs of the people. Under Mawu are the various vodun of the land, the latter being in Egun cosmology, emissaries who are supernaturally equipped to approach Mawu directly on behalf the people. These vodun have shrines that are located in each of the eight quarters and other strategic places in the town (See Simpson, 2001).

\section{The Significance of the Royal Stool (Wheno Aholu J an)}

Apart from the adoption of Tovi-Novi in attending to security matters that 'border on dispute settlement, the pattern of dispute settlement in the traditional court setting in Badagry is also inextricably linked with the royal stool of the Wheno Aholu. This stool is called-the Wheno Aholu Jan (implying 'king's stool'). The stool, which is the equivalent of a 'Listening king', commands an enormous aura of respect among the people whether or not the king is sitting on it. This reveals the fact that the King is able to judge a case by either being physically present, or spiritually represented by this royal stool as well as the entire members of the royal council. Personification of the royal stool also ensures the acceptance of any verdict arrived at, even in the king's absence. 


\section{Team Work and Team Justice}

The separate but mutually dependent security agents have lessons to offer concerning neighbourhood security and team work that extends beyond the frontiers of mere amorphous groups. This is because commitment is given priority by every member of the team. It is important to note that representative individual members of the other three security agents in the town are usually present at the traditional court sittings. This is either in their capacity as security agents whose attention may be needed in effecting the judgments meted out by the court (for example, the Zangbeto), as relations of those whose particular cases are being treated (as in the case of a Tayin) or as a witness to the matter between the disputing parties, as typified by the case' of the area leader (Kogan).

The custodians of the Zangbeto security force are often invited to bring their judicial symbol to traditional court sessions. This symbol is an effigy of the Zangbeto masquerade used in the process of dispute settlement and general vigil keeping in the land. An individual that is banned at the traditional court from performing certain acts is usually handed over to the custodians of Zangbeto, who would put a symbol of the masquerade around the vicinity from which such an individual may have been restricted.

In all, team work is greatly reinforced by the physical presence of the respective agents at the traditional court meetings. These separate but mutually dependent groups have lessons to offer for neighbourhood security conduct related team work. They extend, in essence, beyond the frontiers of mere amorphous groups that are commonly referred to as teams in everyday Nigerian parlance. The team's involvement in their neighbourhood security assignment from inception to completion is thus an indispensable aspect of the structures that uphold the continued maintenance of peace and security (jijoho) among the Egun of Badagry town.

\section{Conclusion: Neighbourhood Security and Enduring Peace}

By examining the network of social relationships that combine to form a formidable indigenous pattern of security ID Badagry town, I have demonstrated how common interests and common loyalties serve as propelling factors in the sustenance of the neighbourhood security functions in the area. Such factors are re-emphasised in the following statement by the incumbent king of Badagry, Wheno Aholu Menu Toyi 1 (200411-12):

The Palace (Honme) holds court sessions in compliance with our tradition and culture for prompt resolution of conflicts, sharp disagreement over land matters, (among communities, individuals and families either through encroachment, illegal entry, improper sale), inheritance, farmland, real estate, ownership of farm produce, fishing rights, matrimonial matters, 
paternity matters, theft, and felony, dispute over the appointments of village Heads (Togan), Quarter security headship (Kogan) form the bulk of matters for conflict resolution .... Most of the matters creating misunderstanding and sharp disagreements listed ... could have been prevented if the Ogu culture of peace was applied.

Team work in neighbourhood security Badagry town is thus evident as has been discussed in the traditional court system that is run by the traditional government, upheld by the values of the land and supported by the security arms that operate individually to ensure the sustenance of peace and harmony.

\section{References}

Akinjogbin, 1.A (1967) Dahomey and Her Neighbours, 1842-1872 London: Clarendon Press Press.

Adamson, H.E (1967) "Law-Ways of the Comanche Indians" in Paul Bohannan (ed) (1967) Law and Warefare.New York: American Museum Source Books in Anthropolgy.

Asiwaju, A.I. (1979) "The Aja-Speaking peoples in Nigeria: A Note on their Origins, Settlements and Cultural adaptation up to 1945" in Africa 49, (1) pp 15-28.

Avognon, J.K. (1994) "The Degree of Billingualism of the Ogu Speakers of Badagry - Implications" in Badagry A Study in History, Culture and Traditions of an Ancient City. Ibadan: Rex Charles Publication.314- 323.

Avoseh, T. 0 (1938) A Short History ofBadagry. Lagos: Ifeolu Printing Works.

Bohannan, P. (1967) Law and Warfare. New York: American Museum Source Book in Anthropology.

De Wheno Aholu Menu Toyi 1. (2004) "The Peace Culture - Desideratum for Socio-Economic and Technological Development for a Nascent Democracy" in Nigeria: A Cultural Perspective to Peace Advocacy. Enugu: Forth Dimension Publishing Co. Ltd. 3-17.

Evans-Pritchard, E.E. (1965) The Position of Women in Primitive Societies and other Essays in Anthropology. London: Faber and Faber.

Falk, M.S. (2005) Law and Anthropology. Oxford: Blackwell Publishing.

Hanks, P. and Potter, S (n. d). "Ethnography" in Encyclopaedic World Dictionary, London: Hamlyn Press, no date 549.

Herskovitz, M. (1977) Dahomey, An Ancient Kingdom. Voll and 2. Evanston: North Western University Press

Hodder, B.W. (1962) "Badagry 1: Slave Port and Mission Centre" in Nigerian Geographical Journal 5 (2) pp 75-86.

Hodder, B.W. (1963) "Badagry 11: One Hundred Years of Change" in Nigerian Geographical Journal 6 (1) pp 17-30.

Mead, Margaret (1970) "The Art and Technology of Fieldwork" in Naroll, and Ronald Cohen: A Handbook of Method in Cultural Anthropology. 
Columbia: Columbia University Press. Mead, M (1977) Letters from the Fields: 1925 - 1975, New York: Harper and Row Publishers. Newbury, E.W. (1965) The Western Slave and its Rulers. Oxford: Clarendon Press.

Oguremi, G.O.; Opeloye, M.O. and Oyeweso S. (1994) Badagry A Study in History, Culture and Traditions of an Ancient City. Ibadan: Rex Charles Publications.

Simpson, A. (1994) "Badagry: The Religious Functions of Agbalata Market" in Badagry A Study in History, Culture and Traditions of an Ancient City. Ibadan: Rex Charles Publication. 305-312.

Simpson, A. (2001) The Culture ofVodun and Ancestor Worship in Badagry Town. Lagos: Interlingua Ltd

Simpson, A. (2004) Oral Tradition and Slave Trade in Nigeria, Ghana and Benin. Paris: United Nations Educational, Scientific and Cultural Organization.

Sturtevant, W.E. (1964) "Studies in Ethnoscience" in American Anthropologist, vol. 66, no.3, part 2, 99-131.

Wax, R.H. (1971) Doing Fieldwork: Warnings and Advice. Chicago: The University of Chicago Press. 